\title{
Joint effect of obesity and TNFA variability on asthma: two international cohort studies
}

\author{
F. Castro-Giner, M. Kogevinas, M. Imboden, R. de Cid, D. Jarvis, M. Mächler, \\ W. Berger, P. Burney, K.A. Franklin, J.R. Gonzalez, J. Heinrich, C. Janson, \\ E. Omenaas, I. Pin, T. Rochat, J. Sunyer, M. Wjst, J-M. Antó, \\ X. Estivill and N.M. Probst-Hensch
}

ABSTRACT: Obesity is a risk factor for asthma. Adipose tissue expresses pro-inflammatory molecules including tumour necrosis factor (TNF), and levels of TNF are also related to polymorphisms in the TNF- $\alpha$ (TNFA) gene. The current authors examined the joint effect of obesity and TNFA variability on asthma in adults by combining two population-based studies.

The European Community Respiratory Health Survey and the Swiss Cohort Study on Air Pollution and Lung and Heart Disease in Adults used comparable protocols, questionnaires and measures of lung function and atopy. DNA samples from 9,167 participants were genotyped for TNFA -308 and lymphotoxin- $\alpha$ (LTA) +252 gene variants.

Obesity and TNFA were associated with asthma when mutually adjusting for their independent effects (odds ratio (OR) for obesity 2.4, 95\% confidence interval (CI) 1.7-3.2; OR for TNFA -308 polymorphism $1.3,95 \% \mathrm{Cl} 1.1-1.6)$. The association of obesity with asthma was stronger for subjects carrying the $G / A$ and A/A TNFA -308 genotypes compared with the more common G/G genotype, particularly among nonatopics (OR for $\mathrm{G} / \mathrm{A}$ and $A / A$ genotypes $6.1,95 \% \mathrm{Cl} 2.5-14.4$; OR for $\mathrm{G} / \mathrm{G}$ genotype $1.7,95 \% \mathrm{Cl}$ 0.8-3.3).

The present findings provide, for the first time, evidence for a complex pattern of interaction between obesity, a pro-inflammatory genetic factor and asthma.

KEYWORDS: Asthma, atopy, genetic polymorphism, obesity, tumour necrosis factor- $\alpha$

$\mathrm{T}$ here is increasing evidence suggesting that obesity is a risk factor for asthma in children and adults [1-3]. Obesity has been associated with both incident and prevalent asthma as well as with severity of the disease. Results from cohort studies have not, however, been consistent. Experimental studies support this association but the mechanisms linking obesity with asthma are complex and remain uncertain [2, 4-7]. Obesity affects pulmonary physiology and induces changes in immunity or inflammatory status. Adipose tissue expresses a number of pro-inflammatory molecules, including tumour necrosis factor (TNF), in a pattern that could be analogous to the immune function of T-lymphocytes and macrophages [8].

Twin studies suggest that obesity and asthma may be caused by shared genetic (genetic pleiotropy) risk factors [9]. Some genes associated with obesity are located on asthma consensus loci on chromosomic regions $5 q, 6 p, 11 q$ and $12 q[6]$, and TNF- $\alpha$
(TNFA) is among the few genes that have been associated with both asthma and obesity $[4,5]$.

TNF is a potent pro-inflammatory cytokine, mainly secreted by macrophages. TNF is involved in the regulation of a wide spectrum of biological processes, including cell proliferation, differentiation, apoptosis, lipid metabolism and coagulation, and has been implicated in a variety of diseases, including autoimmune diseases, insulin resistance, cancer and inflammation of asthmatic airways. TNFA and lymphotoxin- $\alpha$ (LTA; also named TNF $\beta$ ) genes are members of the TNF superfamily. TNFA and LTA are located within the class III region of the major histocompatibility complex region on chromosome $6 \mathrm{p} 21.3$, in a cluster of $13 \mathrm{~kb}$, which also includes lymphotoxin- $\beta$, a region previously linked to asthma in different genome scans. Polymorphisms in TNFA and LTA may affect levels of TNF in the airways. The TNFA -308 G/A polymorphism, located in the promoter region of TNFA, has been associated with
AFFILIATIONS

For affiliations, see

Acknowledgements section.

CORRESPONDENCE

M. Kogevinas

Centre for Research in Environmental Epidemiology

88 Dr Aiguader Rd

Barcelona 08003

Spain

Fax: 34933160575

E-mail: kogevinas@creal.cat

Received:

September 122008

Accepted after revision:

January 102009

\section{SUPPORT STATEMENT}

This study was supported by grants from the MaratoTV3, Catalonia,

Spain; Swiss National Science

Foundation, Switzerland; Lung

League Zürich, Switzerland; Genome Spain and Spanish Ministry of Science and Innovation. Additional funding was available in each research centre for data collection.

STATEMENT OF INTEREST

None declared. 
increased promoter activity and secretion of TNF [10]. The LTA $+252 \mathrm{~A} / \mathrm{G}$ polymorphism, located in the first intron of the $L T A$ gene, seems to be associated with a high LTA expression [11]. A recent meta-analysis that included the population reported in the current study has shown that the TNFA -308 A and LTA +252 $G$ alleles are both positively associated with asthma [12].

In the current study, the evaluation of a joint effect of obesity and genetic variants in the TNFA and LTA genes on asthma is presented, by examining different proposed pathways associating these biological factors with respect to this disease.

\section{MATERIAL AND METHODS \\ Study population}

The analyses in the current report are based on two studies. The European Community Respiratory Health Survey (ECRHS) is a population-based cohort study conducted in 10 countries [13, 14]. The population-based Swiss Cohort Study on Air Pollution and Lung and Heart Disease in Adults (SAPALDIA) was conducted in eight Swiss communities [15, 16]. Initially, 5,065 participants from ECRHS and 6,071 participants from SAPALDIA with complete interview data and DNA samples for genotyping were included [12]. Some subjects from Basel, Switzerland $(n=400)$, were initially included in both datasets, but remained only in the SAPALDIA cohort during the analyses. Due to differences between the two studies in age at inclusion, the present analysis was restricted to the 9,167 subjects who were aged $<50$ yrs at inclusion. Subjects in both studies could be considered as being mainly of EuropeanCaucasian origin. Ethical approval was obtained for each centre from the appropriate institutional ethics committee and written consent was obtained from each participant.

\section{Asthma and atopy assessment and obesity evaluation}

ECRHS and SAPALDIA used identical questionnaires for assessment of respiratory symptoms and asthma. Asthma status at baseline was evaluated in the early 1990s (ECRHS-I and SAPALDIA-I), while the effects of changes in obesity and asthma were assessed at follow-up for both cohorts. The median length of follow-up was 8.9 yrs. The asthma definitions used in the present analysis were similar to those used in previous publications [12,17]. All subjects defined as having asthma had responded positively to an initial question "Have you ever had asthma?" The main asthma definition of "current asthma" was based on further positive responses to either of two questions: "Have you had an attack of asthma in the last 12 months?" or "Are you currently taking any medicines including inhalers, aerosols or tablets for asthma?" "Physiciandiagnosed asthma" was defined as a further positive response to the question "Was this confirmed by a doctor?"

Height and weight were assessed in both studies (table 1). Body mass index (BMI) was calculated as weight divided by squared height in metres. BMI was divided into four categories: underweight (BMI $<20 \mathrm{~kg} \cdot \mathrm{m}^{-2}$ ), normal weight (BMI 20 to $<25 \mathrm{~kg} \cdot \mathrm{m}^{-2}$ ), overweight $\left(\right.$ BMI $\geqslant 25$ to $<30 \mathrm{~kg} \cdot \mathrm{m}^{-2}$ ) and obese $\left(\mathrm{BMI} \geqslant 30 \mathrm{~kg} \cdot \mathrm{m}^{-2}\right)$.

Skin prick tests were performed in ECRHS and SAPALDIA

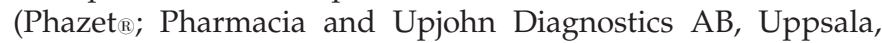
Sweden). At baseline in both studies, atopic subjects were defined as having positive tests to at least one common aero-allergen (Dermatophagoides pteronyssinus, timothy grass, cat and Cladosporium herbarum).

\section{Candidate single nucleotide polymorphism selection and genotyping}

On the basis of previous studies and functional data [10-12], two single nucleotide polymorphisms (SNPs) were selected for genetic analysis in the two cohorts, TNFA -308 (rs1800629) and LTA +252 (rs909253). In SAPALDIA, these polymorphisms were genotyped by real-time PCR. In ECRHS, SNPs were genotyped using the SNPlex ${ }^{\mathrm{TM}}$ platform (Applied Biosystems, Foster City, CA, USA). Genotyping was performed at the Centre for Genomic Regulation in the Barcelona Node of the Centro Nacional de Genotipado in Spain. The agreement in genotyping in subjects from Basel, Switzerland $(n=400)$, who were included in both ECRHS and SAPALDIA and were genotyped by both methods, was $99.8 \%$. Genotype distribution for both alleles was consistent with Hardy-Weinberg equilibrium (HWE) in the control group $(\mathrm{p}>0.05)$. A previous analysis of these cohorts [12] found similar effects of TNFA -308 and $L T A+252$ on asthma, possibly due to strong linkage disequilibrium between the loci (Chi-squared $=7516.29$, disequilibrium

\begin{tabular}{|c|c|c|c|c|c|c|}
\hline \multirow[t]{3}{*}{ TABLE 1} & \multicolumn{6}{|c|}{$\begin{array}{l}\text { Characteristics of the population in the European } \\
\text { Community Respiratory Health Survey (ECRHS) } \\
\text { and the Swiss Cohort Study on Air Pollution and } \\
\text { Lung and Heart Disease in Adults (SAPALDIA) } \\
\text { studies }\end{array}$} \\
\hline & \multicolumn{3}{|c|}{ Controls } & \multicolumn{3}{|c|}{ Cases of current asthma } \\
\hline & ECRHS & SAPALDIA & $\begin{array}{c}p- \\
\text { value }\end{array}$ & ECRHS & SAPALDIA & $\begin{array}{c}\mathrm{p}- \\
\text { value }\end{array}$ \\
\hline Subjects $n$ & 4224 & 4364 & & 426 & 132 & \\
\hline Age yrs & $34.2 \pm 7.2$ & $36.3 \pm 8.8$ & $<0.01$ & $33.7 \pm 7.1$ & $36.5 \pm 8.9$ & $<0.01$ \\
\hline \multicolumn{7}{|l|}{ Sex } \\
\hline Male & $2036(48.2)$ & 2197 (50.5) & 0.03 & $172(40.4)$ & $60(45.8)$ & 0.32 \\
\hline Female & 2188 (51.8) & 2149 (49.4) & & 254 (59.6) & $71(54.1)$ & \\
\hline \multicolumn{7}{|c|}{ Smoking status } \\
\hline Never & $1796(42.5)$ & 2021 & $<0.01$ & $219(51.7)$ & $65(49.2)$ & 0.16 \\
\hline Ex & $892(21.1)$ & $947(21.7)$ & & $93(21.9)$ & 39 (29.5) & \\
\hline Current & $1534(36.3)$ & $1392(31.9)$ & & $112(26.4)$ & $28(21.2)$ & \\
\hline \multicolumn{7}{|l|}{ BMI $\mathrm{kg} \cdot \mathrm{m}^{-2}$} \\
\hline Mean $\pm \mathrm{SD}$ & $24.1 \pm 3.8$ & $23.8 \pm 3.6$ & $<0.01$ & $24.7 \pm 4.6$ & $24.5 \pm 4.5$ & 0.62 \\
\hline$<20$ & $387(9.9)$ & $688(15.8)$ & $<0.01$ & $33(8.3)$ & $16(12.2)$ & 0.31 \\
\hline 20 to $<25$ & $2194(56.2)$ & $2495(56.7)$ & & $218(54.9)$ & $77(58.8)$ & \\
\hline 25 to $<30$ & $1072(27.5)$ & 990 & & $96(24.2)$ & $25(19.1)$ & \\
\hline$\geqslant 30$ & $249(6.4)$ & $203(4.7)$ & & $50(12.6)$ & $13(9.9)$ & \\
\hline \multicolumn{7}{|l|}{ TNFA -308} \\
\hline$G / G$ & $2809(72.1)$ & $3246(74.4)$ & 0.04 & $248(62.4)$ & $99(75.0)$ & 0.02 \\
\hline$G / A$ & $980(25.1)$ & $1011(23.2)$ & & $132(33.2)$ & $31(23.5)$ & \\
\hline$A / A$ & $110(2.3)$ & $103(2.4)$ & & $17(4.3)$ & $2(1.5)$ & \\
\hline \multicolumn{7}{|l|}{$L T A+252$} \\
\hline$A / A$ & $1997(47.5)$ & 2089 (47.9) & 0.52 & $165(38.8)$ & $67(51.6)$ & $<0.01$ \\
\hline$A / G$ & $1750(41.6)$ & $1832(42.0)$ & & $202(47.5)$ & $59(44.7)$ & \\
\hline$G / G$ & $455(10.8)$ & $439(10.1)$ & & $58(13.6)$ & $6(4.5)$ & \\
\hline
\end{tabular}


constant $\left.\left(D^{\prime}\right)=0.98, \mathrm{p}<0.001\right)$. Results were also similar for the present analysis evaluating obesity, and results for $L T A+252$ are, therefore, not shown.

\section{Statistical analysis}

The statistical analyses were performed using logistic regression and SNPassoc (version 1.5-1) R package (version 2.6.1) $[18,19]$. Logistic regression models were used, adjusted for country (ECRHS) or study area (SAPALDIA), sex, age and smoking status. SNPs were tested in control samples for deviations from HWE [20]. Genotype distribution for both alleles was consistent with $\mathrm{HWE}$ in the control group $(\mathrm{p}>0.05) . D^{\prime}$ and Chi-squared $\mathrm{p}$-values for marker independence were estimated to determine linkage disequilibrium between both genetic markers. Population stratification in ECRHS data was assessed using two different methods. First, the analysis of 26 unlinked markers (supplementary table E1) was performed by the genomic control approach [21] used in the earlier analysis [12]. It was found that population stratification had a minimal effect (inflation factor 1.06). Secondly, analysis using EIGENSTRAT software (version 1.01) [22] using the same 26 markers showed no evidence of population stratification (supplementary fig. E1).

\section{RESULTS}

The general characteristics of the study population are summarised in table 1. Among controls, significant but slight differences were observed between cohorts for mean age, sex, smoking status and mean BMI. Compared with controls, cases with current asthma were more often females and younger, and reported less smoking.

The multivariate analysis of obesity, TNFA -308 polymorphism and current asthma (table 2) indicated that both obesity and the TNFA -308 polymorphism are associated with asthma. The risk estimates for TNFA -308 and obesity were very similar in the unadjusted models compared with the model adjusting mutually for both risk factors, indicating that the effect of each factor is not dependent on the other. Adjustment by smoking status or further adjustment by atopy did not modify the risk estimates. Similar associations were observed for

\begin{tabular}{|c|c|c|}
\hline TABLE 2 & $\begin{array}{l}\text { Multivariate model as } \\
\text { with tumour necrosis } \\
\text { polymorphism and o }\end{array}$ & $\begin{array}{l}\text { ociating current asthma } \\
\text { actor- } \alpha \text { (TNFA) }-308 \\
\text { esity }\end{array}$ \\
\hline Variables & OR $(95 \% \mathrm{Cl})$ & Mutually adjusted OR $(95 \% \mathrm{Cl})$ \\
\hline \multicolumn{3}{|l|}{ BMI $\mathrm{kg} \cdot \mathrm{m}^{-2}$} \\
\hline$<20$ & $0.78(0.56-1.07)$ & $0.76(0.54-1.06)$ \\
\hline 20 to $<25$ & 1 (ref) & 1 (ref) \\
\hline 25 to $<30$ & $0.95(0.75-1.20)$ & $0.91(0.71-1.15)$ \\
\hline$\geqslant 30$ & $2.36(1.72-3.21)$ & $2.23(1.60-3.06)$ \\
\hline \multicolumn{3}{|l|}{ TNFA -308 } \\
\hline GG & 1 (ref) & 1 (ref) \\
\hline GA & $1.33(1.08-1.62)$ & $1.41(1.14-1.73)$ \\
\hline$A A$ & $1.41(0.83-2.28)$ & $1.48(0.85-2.42)$ \\
\hline
\end{tabular}

physician-diagnosed asthma, while no clear pattern was observed between BMI categories and atopy.

The percentages of underweight and obese subjects were higher for carriers of the A/A TNFA -308 genotype (18\% and $2 \%$, respectively) compared with the more frequent $G / G$ genotype ( $13 \%$ and $1 \%$, respectively). These differences were only statistically significant for underweight subjects $(p=0.02)$. The association of TNFA -308 with underweight was only observed in the ECRHS and not in SAPALDIA but the difference between studies was not statistically significant.

Figure 1 shows risk estimates for obesity and current asthma after stratifying by TNFA -308 genotypes. The analysis was performed combining $G / A$ and $A / A$ carriers (dominant genetic model) because analysis for each genotype was not possible due to the low prevalence of $A / A(3 \%)$. The risk tended to be higher for those with the $G / A$ and $A / A$ genotypes (odds ratio (OR) $3.17,95 \%$ confidence interval (CI) 1.73-5.66) compared with the $G / G$ genotype (OR 1.94, 95\% CI 1.28-2.85), but the interaction was not statistically significant $(p=0.40)$. This difference in risk was more pronounced among nonatopics for current asthma (OR 6.09, 95\% CI 2.49-14.39) and physiciandiagnosed asthma (OR 5.62, 95\% CI 2.79-11.02), while the TNFA -308 polymorphisms did not seem to modify the effect of obesity and asthma in atopics (OR 1.67, 95\% CI 0.77-3.28, and OR 1.66, 95\% CI 0.84-3.15, respectively). The interaction between TNFA and obesity in relation to asthma among nonatopics was statistically significant $(p=0.05$ for current asthma and $\mathrm{p}=0.03$ for physician-diagnosed asthma).

The association of TNFA -308 with asthma stratified by BMI is shown in table 3 (contrary to figure 1 , which showed the ORs for BMI stratified by TNFA -308). A positive association of TNFA -308 polymorphisms with current asthma was observed for all subjects (OR 1.34, 95\% CI 1.10-1.62). The highest risks were observed for those underweight (OR 1.94, 95\% CI 1.003.68 ) and obese subjects (BMI $\geqslant 30 \mathrm{~kg} \cdot \mathrm{m}^{-2}$; OR $1.70,95 \% \mathrm{CI}$ 0.89-3.19). The increased risk for TNFA -308 among obese

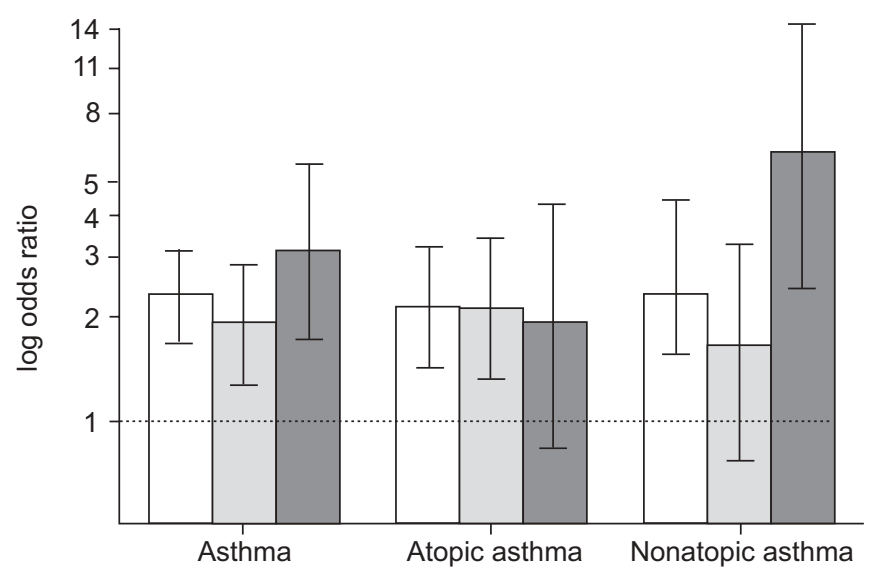

FIGURE 1. Odds ratios (bars) and $95 \%$ confidence intervals (lines) for the association of obesity (body mass index $(\mathrm{BMI}) \geqslant 30 \mathrm{~kg} \cdot \mathrm{m}^{-2}$ ) and current asthma by atopy and tumour necrosis factor- $\alpha$ (TNFA) -308 genotypes. $\square$ : all subjects; $\square$ : G/ $G$; $: G / A+A / A$. The reference group corresponded to subjects with normal weight (BMl 20 to $<25 \mathrm{~kg} \cdot \mathrm{m}^{-2}$ ). The logistic regression was adjusted for country, age, sex and smoking status. 


\begin{tabular}{|c|c|c|c|c|c|c|c|}
\hline \multirow[t]{3}{*}{ TABLE 3} & \multicolumn{7}{|c|}{$\begin{array}{l}\text { Association of tumour necrosis factor- } \alpha \text { (TNFA) }-308 \mathrm{G} / \mathrm{A}+\mathrm{A} / \mathrm{A} \text { genotype and asthma stratified by body mass index (BMI) } \\
\text { categories }\end{array}$} \\
\hline & & \multicolumn{2}{|c|}{ All } & \multicolumn{2}{|c|}{ Atopic asthma } & \multicolumn{2}{|c|}{ Nonatopic asthma } \\
\hline & & OR $(95 \% \mathrm{Cl})^{\#}$ & p-value & OR $(95 \% \mathrm{Cl})^{\#}$ & p-value & OR $(95 \% \mathrm{Cl})^{\#}$ & p-value \\
\hline \multicolumn{2}{|c|}{ Current asthma } & $1.34(1.10-1.62)$ & & $1.35(1.05-1.72)$ & & $1.33(0.93-1.87)$ & \\
\hline \multicolumn{2}{|l|}{$\mathrm{BMl}<20$} & $1.94(1.00-3.68)$ & 0.24 & $2.32(1.02-5.24)$ & 0.23 & $2.29(0.68-7.43)$ & 0.21 \\
\hline \multicolumn{2}{|c|}{ BMI 20 to $<25$} & $1.27(0.97-1.64)$ & ref & $1.25(0.90-1.73)$ & ref & $1.05(0.63-1.70)$ & ref \\
\hline \multicolumn{2}{|c|}{ BMl 25 to $<30$} & $1.52(0.99-2.30)$ & 0.53 & $1.64(0.95-2.78)$ & 0.43 & $1.17(0.54-2.38)$ & 0.83 \\
\hline \multicolumn{2}{|l|}{$\mathrm{BMI} \geqslant 30$} & $1.70(0.89-3.19)$ & 0.41 & $1.05(0.41-2.55)$ & 0.66 & $3.15(1.18-8.54)$ & 0.05 \\
\hline \multicolumn{2}{|c|}{ Physician-diagnosed asthma } & $1.10(0.93-1.29)$ & & $1.18(0.96-1.46)$ & & $0.94(0.70-1.24)$ & \\
\hline \multicolumn{2}{|l|}{$\mathrm{BMI}<20$} & $1.43(0.85-2.36)$ & 0.30 & $1.61(0.84-3.06)$ & 0.45 & $1.58(0.66-3.56)$ & 0.10 \\
\hline \multicolumn{2}{|c|}{ BMI 20 to $<25$} & $1.04(0.83-1.09)$ & ref & $1.09(0.83-1.43)$ & ref & $0.70(0.45-1.06)$ & ref \\
\hline \multicolumn{2}{|c|}{ BMI 25 to $<30$} & $1.13(0.78-1.62)$ & 0.80 & $1.32(0.80-2.12)$ & 0.58 & $0.93(0.52-1.59)$ & 0.46 \\
\hline \multicolumn{2}{|l|}{$\mathrm{BMI} \geqslant 30$} & $1.76(0.99-3.10)$ & 0.10 & $1.32(0.57-2.99)$ & 0.78 & $1.93(0.85-4.26)$ & 0.03 \\
\hline
\end{tabular}

OR: odds ratio; $\mathrm{Cl}$ : confidence interval; ref: reference value. ${ }^{*}$ : logistic regression adjusted by country, sex, age and smoking status. ": for interaction between $T_{N F}-308$ $\mathrm{G} / \mathrm{A}+\mathrm{A} / \mathrm{A}$ and $\mathrm{BMI}$ categories; reference categories $\mathrm{BMI} 20$ to $<25 \mathrm{~kg} \cdot \mathrm{m}^{-2}$ and $\mathrm{G} / \mathrm{G}$ genotype.

subjects were observed in both SAPALDIA (OR 2.42) and ECRHS (OR 1.56), while there was heterogeneity between studies in the results for underweight (test for heterogeneity $\mathrm{Q}=5.00, \mathrm{p}=0.03$ ). Among underweight subjects, the increased risk of current asthma was associated with TNFA -308 irrespective of atopic status (table 3), while the increased risk of TNFA -308 among obese subjects was only observed for nonatopics, with an OR of 3.15 (95\% CI 1.18-8.54) for current asthma and 1.93 (95\% CI 0.85-4.26) for physician-diagnosed asthma. The interaction term for TNFA -308 and obesity was the same as that shown for figure 1.

\section{DISCUSSION}

In the present study, the joint effects of obesity and the TNFA gene were evaluated in adults with asthma. The findings suggest that obesity and TNFA are associated with asthma in a complex pattern that involves both independent and combined pathways, and that some of these pathways may be modified by sex and atopic status. The combination of two studies increased statistical power but also served to verify the consistency of findings in two populations examined with similar protocols but by different research groups.

The mechanisms through which obesity provokes asthma remain unclear. Common genetic pathways have been proposed as an explanation for the covariation of obesity and asthma [5]. The current study is the first to evaluate both obesity and TNFA variants simultaneously in a large population sample. A model showing the possible links between obesity, TNF and asthma is proposed in figure 2 .

There is rising evidence that links both obesity and TNFA variants to asthma (pathways A and B, fig. 2). Results of several cross-sectional and prospective studies [1, 2, 4, 8], as well as a recent meta-analysis [1], are in favour of obesity being a risk factor for asthma (pathway A, fig. 2). Results from the ECRHS and SAPALDIA studies, particularly the effect of weight gain during the follow-up period on the occurrence of new-onset asthma, support these findings [23]. Obesity may affect the pulmonary physiology and modify the immunological system, leading to pro-inflammatory processes [4-6, 8]. Some studies have suggested an increased risk for asthma and asthma-related symptoms among underweight subjects [24-27]. The reasons for the impact of underweight on asthma are unclear [24], and further research is needed to elucidate potential pathways. Although this effect was not observed in the current study, an increased risk of TNFA -308 was seen among underweight subjects, which may suggest a role of underweight and systemic inflammatory state on asthma.

The TNFA -308 polymorphism has been linked with an increased TNF expression [10] and has been previously associated with asthma [12]. The current results indicate that TNFA -308 is associated with asthma (pathway B, fig. 2) but not with atopy [12].

Only a weak association was found between TNFA -308 and obesity (pathway C, fig. 2), and an association was also found with underweight, although this was observed only in the ECRHS and not in SAPALDIA study. Results from a metaanalysis suggest that TNFA -308 is associated with the

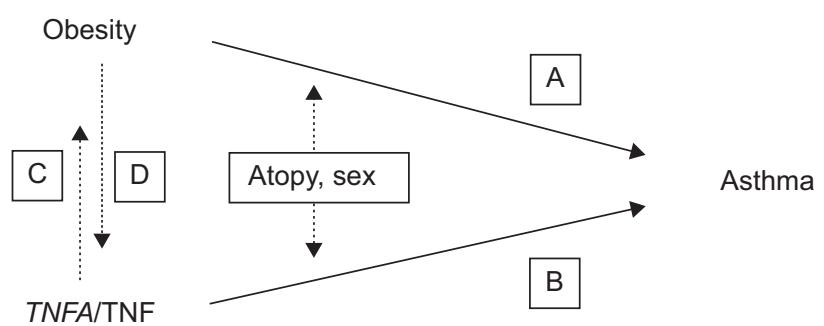

FIGURE 2. Pathways associating obesity, the tumour necrosis factor- $\alpha$ (TNFA) gene/tumour necrosis factor (TNF) cytokine and asthma. _-independent effects of obesity (line A) and TNFA/TNF (line B) on asthma, for which there exists strong evidence. ..... pathways for which epidemiological evidence is less clear; the potential interaction of obesity and TNFA (lines C and D) and the potential modification of these effects by atopy and sex. 
development of obesity [28]. In contrast, experimental studies suggest that TNF is involved in body weight homeostasis by increasing lipolysis, favouring muscle cell catabolism and stimulating general proteolysis [29].

In a reverse pathway, TNF could be involved in inflammatory changes produced by obesity (pathway D, fig. 2). This pathway could only be examined indirectly by evaluating whether the effect of obesity on asthma was modulated by the TNFA -308 polymorphism. As hypothesised, the asthma risk associated with obesity was strongest in carriers of the TNF -308 A allele. This observation is consistent with the hypothesis that the influence of adipose tissue on TNF signalling is genotype dependent. Adipose tissue expresses several cytokines, including TNF- $\alpha$ [8], that may simulate the immune function of T-lymphocytes and macrophages [4]. Increased levels of TNF in serum have been observed in obese subjects [30, 31], as well as in asthmatics [32]. TNFmediated inflammation is common in both obesity and asthma and it is plausible that it is upregulated in both conditions [5].

It has been suggested that the effect of obesity on asthma and atopy could be sex dependent, being greater in post-pubertal and adult females than in males $[1,4,6,8,23]$. The current results suggest a slightly stronger effect of obesity on physician-diagnosed asthma among females compared with males. The present study also reported an increased risk for atopy in females and a significant interaction between sex and obesity for atopy. However, overall results are inconsistent [1, $4,7,8,14]$, including those in a recent meta-analysis [33].

The current study found that the effect of obesity was stronger for subjects with nonatopic asthma. Other studies have also reported similar findings [34, 35], or have found an association for asthma but not for other atopic diseases [36, 37]. GILLILAND et al. [34] and KRONANDER et al. [35] found an increased risk for nonatopic asthma regardless of sex, while they observed an increased risk for atopic asthma only among obese females. Raised levels of high-sensitivity C-reactive protein, an inflammatory marker known to be related to smoking, obesity and cardiovascular disease, were found to be significantly associated with respiratory symptoms and nonallergic asthma but not with allergic asthma [38].

The current analysis presents, for the first time a joint evaluation of obesity and TNF in a large population-based study. Despite the large sample size, the evaluation of asthma and obesity in relation to the minor TNFA -308 genotype $(A / A)$ was based on small numbers. In addition, some of the pathways evaluated related to obesity could have different effects in pre- and post-menopausal females. In current study, most females were pre-menopausal. Other issues that could not be adequately addressed in the present study regard other measures of obesity, such as waist-tohip ratio, that have been shown to be associated with a high risk of cardiovascular diseases [39]. Finally, the analysis of the impact of obesity on TNF- $\alpha$ signalling would have been more informative had circulating TNF- $\alpha$ levels been measured.

The present study strengthens the existing evidence for an effect of obesity and tumour necrosis factor on asthma, and shows for the first time that obesity interacts with genetic factors in the causation of asthma. In conclusion, the study shows that obesity and tumour necrosis factor are associated with asthma in a complex pattern that involves both independent and combined effects.

\section{ACKNOWLEDGEMENTS}

The authors' affiliations are as follows. F. Castro-Giner and J.R. Gonzalez: Centre for Research in Environmental Epidemiology (CREAL), Municipal Institute of Medical Research (IMIMHospital del Mar) and CIBER Epidemiologia y Salud Pública (CIBERESP), Barcelona, Spain. M. Kogevinas: Centre for Research in Environmental Epidemiology (CREAL), Municipal Institute of Medical Research (IMIM-Hospital del Mar) and CIBER Epidemiologia y Salud Pública (CIBERESP), Barcelona; and Medical School, University of Crete, Heraklion, Greece. M. Imboden: Institutes of Social and Preventive Medicine, and Surgical Pathology, Molecular Epidemiology/Cancer Registry, University of Zurich and University Hospital Zurich and Institute of Medical Genetics, Division of Medical Molecular Genetics and Gene Diagnostics, University of Zurich, Zurich, Switzerland. R. de Cid: CIBER Epidemiologia y Salud Pública (CIBERESP) and Genes and Disease Program, Center for Genomic Regulation, Barcelona, Spain. D. Jarvis and P. Burney: Respiratory Epidemiology and Public Health Group, National Heart and Lung Institute, Imperial College, London, UK. M. Mächler and N.M. ProbstHensch: Institutes of Social and Preventive Medicine, and Surgical Pathology, Molecular Epidemiology/Cancer Registry, University of Zurich and University Hospital Zurich, Zurich, Switzerland. W. Berger: Institute of Medical Genetics, Division of Medical Molecular Genetics and Gene Diagnostics, University of Zurich, Zurich, Switzerland. K.A. Franklin: Dept of Respiratory Medicine, University Hospital, Umeå, Sweden. J. Heinrich: Institute of Epidemiology, Helmholtz Centre, Munich, Germany. C. Janson: Dept of Medical Sciences, Respiratory Medicine and Allergology, Uppsala University, Uppsala, Sweden. E. Omenaas: Haukeland University Hospital Bergen, Bergen, Norway. I. Pin: Inserm, U823, Centre de Recherche Albert Bonniot, Immunobiologie et Immunothérapie des cancers, La Tronche, University Joseph Fourier and Centre Hospitalier Universitaire de Grenoble, Grenoble, France. T. Rochat: Division of Pulmonary Medicine, University Hospitals of Geneva, Geneva, Switzerland. J. Sunyer and J-M. Antó: Centre for Research in Environmental Epidemiology (CREAL), Municipal Institute of Medical Research (IMIM-Hospital del Mar), CIBER Epidemiologia y Salud Pública (CIBERESP) and Universitat Pompeu Fabra, Barcelona, Spain. M. Wjst: German Research Center for Environmental Health, Helmholtz Centre GSF, Munich, Germany. X. Estivill: CIBER Epidemiologia y Salud Pública (CIBERESP), Genes and Disease Program, Center for Genomic Regulation, and Universitat Pompeu Fabra, Barcelona, Spain.

The SAPALDIA study could not have been done without the help of the study participants, technical and administrative support, the medical teams and field workers at the local study sites as well as the entire SAPALDIA Team. The authors also thank E. Glaus for extracting the DNA and O. Senn for genotyping (both University of Zurich, Zurich, Switzerland).

Local Swiss fieldworkers were as follows. Aarau: M. Broglie, M. Bünter and D. Gashi. Basel: R. Armbruster, T. Damm, U. Egermann, M. Gut, L. Maier, A. Vögelin and L. Walter. Davos: D. Jud and N. Lutz. Geneva: M. Ares, M. Bennour, B. Galobardes and E. Namer. Lugano: B. Baumberger, S. Boccia Soldati, E. Gehrig-Van Essen and S. Ronchetto. Montana: 
C. Bonvin and C. Burrus. Payerne: S. Blanc, A.V. Ebinger, M.L. Fragnière and J. Jordan. Wald: R. Gimmi, N. Kourkoulos and U. Schafroth.

Administrative staff: N. Bauer, D. Baehler, C. Gabriel and R. Nilly.

Study directorate: T. Rochat, U. Ackermann-Liebrich, J.M. Gaspoz, P. Leuenberger, L.J.S. Liu, N.M. Probst-Hensch and C. Schindler.

Scientific team: J.C. Barthélémy, W. Berger, R. Bettschart, A. Bircher, G. Bolognini, O. Brändli, M. Brutsche, L. Burdet, M. Frey, M.W. Gerbase, D. Gold, W. Karrer, R. Keller, B. Knöpfli, N. Künzli, U. Neu, L. Nicod, M. Pons, E. Russi, P. Schmid-Grendelmeyer, J. Schwartz, P. Straehl, J.M. Tschopp, A. von Eckardstein, J.P. Zellweger and E. Zemp Stutz.

Scientific team at coordinating centres: P.O. Bridevaux, I. Curjuric, S.H. Downs, D. Felber Dietrich, A. Gemperli, D. Keidel, M. Imboden, P. Staedele-Kessler and G.A. Thun.

The ECRHS list of principal investigators and the senior scientific team are as follows (\#: members of the ECRHS Steering Committee). Melbourne, Australia: M. Abramson, R. Woods, E.H. Walters, F. Thien and G. Benke. South Antwerp and Antwerp City, Belgium: P. Vermeire ${ }^{\#}$, J. Weyler, M. Van Sprundel and V. Nelen. Tartu, Estonia: R. Jogi and A. Soon. Paris, France: F. Neukirch", B. Leynaert", R. Liard and M Zureik. Grenoble, France: I. Pin, J. Ferran-Quentin. Erfurt, Germany: J. Heinrich ${ }^{\#}$, M. Wjst", C. Frye and I. Meyer. Reykjavik, Iceland: T. Gislason\#" Turin, Italy: M. Bugiani, P. Piccioni, A. Carosso, W. Arossa, E. Caria, G. Castiglioni, E. Migliore, C. Romano, D. Fabbro, G. Ciccone, C. Magnani, P. Dalmasso, R. Bono, G. Gigli, A. Giraudo, M.C. Brussino, C. Bucca and G. Rolla. Verona, Italy: R. de Marco", G. Verlato, E. Zanolin, S. Accordini, A. Poli, V. Lo Cascio and M. Ferrari. Pavia, Italy: A. Marinoni, S. Villani, M. Ponzio, F. Frigerio, M. Comelli, M. Grassi, I. Cerveri ${ }^{\#}$ and A. Corsico. Groningen, the Netherlands: J. Schouten". Bergen, Norway: A. Gulsvik, E. Omenaas, C. Svanes ${ }^{\#}$ and B. Laerum. Barcelona, Spain: J-M. Antó\#, J. Sunyer", M. Kogevinas, J.P. Zock, X. Basagana, A. Jaen and

F. Burgos. Huelva, Spain: J. Maldonado, A. Pereira and J.L. Sanchez. Albacete, Spain: J. Martinez-Moratalla Rovira and E. Almar. Galdakao, Spain: N. Muniozguren and I. Urritia. Oviedo, Spain: F. Payo. Uppsala, Sweden: C. Janson", G. Boman, D. Norback and M. Gunnbjornsdottir. Gothenburg, Sweden: K. Toren, L. Lillienberg, A. Dahlman-Höglund and R. Sundberg. Umeå, Sweden: E. Norrman, M. Soderberg, K.A. Franklin, B. Lundback, B. Forsberg and L. Nystrom. Basel, Switzerland: N. Künzlï, B. Dibbert, M. Hazenkamp, M. Brutsche and U. Ackermann-Liebrich". London, UK: P. Burney", S. Chinn ${ }^{\#}$ and D. Jarvis\#. Norwich, UK: D. Jarvis and B. Harrison. Ipswich, UK: D. Jarvis, R. Hall and D. Seaton. Portland, OR, USA: M. Osborne, S. Buist, W. Vollmer and L. Johnson.

\section{REFERENCES}

1 Ford ES. The epidemiology of obesity and asthma. J Allergy Clin Immunol 2005; 115: 897-909.
2 Matricardi PM, Gruber C, Wahn U, Lau S. The asthmaobesity link in childhood: open questions, complex evidence, a few answers only. Clin Exp Allergy 2007; 37: 476-484.

3 Chinn S. Asthma and obesity: where are we now? Thorax 2003; 58: 1008-1010.

4 Beuther DA, Weiss ST, Sutherland ER. Obesity and asthma. Am J Respir Crit Care Med 2006; 174: 112-119.

5 Weiss ST. Obesity: insight into the origins of asthma. Nat Immunol 2005; 6: 537-539.

6 Tantisira KG, Weiss ST. Complex interactions in complex traits: obesity and asthma. Thorax 2001; 56: Suppl. 2, ii64ii73.

7 Shore SA. Obesity and asthma: lessons from animal models. J Appl Physiol 2007; 102: 516-528.

8 Hersoug LG, Linneberg A. The link between the epidemics of obesity and allergic diseases: does obesity induce decreased immune tolerance? Allergy 2007; 62: 1205-1213.

9 Hallstrand TS, Fischer ME, Wurfel MM, Afari N, Buchwald D, Goldberg J. Genetic pleiotropy between asthma and obesity in a community-based sample of twins. J Allergy Clin Immunol 2005; 116: 1235-1241.

10 Wilson AG, Symons JA, McDowell TL, McDevitt HO, Duff GW. Effects of a polymorphism in the human tumor necrosis factor- $\alpha$ promoter on transcriptional activation. Proc Natl Acad Sci USA 1997; 94: 3195-3199.

11 Messer G, Spengler U, Jung MC, et al. Polymorphic structure of the tumor necrosis factor (TNF) locus: an NcoI polymorphism in the first intron of the human TNF- $\beta$ gene correlates with a variant amino acid in position 26 and a reduced level of TNF- $\beta$ production. J Exp Med 1991; 173: 209-219.

12 Castro-Giner F, Kogevinas M, Mächler M, et al. TNFA $308 \mathrm{G}>\mathrm{A}$ in two international population-based cohorts and risk of asthma. Eur Respir J 2008; 32: 350-361.

13 Burney PG, Luczynska C, Chinn S, Jarvis D. The European Community Respiratory Health Survey. Eur Respir J 1994; 7: 954-960.

14 Jarvis D, Chinn S, Potts J, Burney P. Association of body mass index with respiratory symptoms and atopy: results from the European Community Respiratory Health Survey. Clin Exp Allergy 2002; 32: 831-837.

15 Martin BW, Ackermann-Liebrich U, Leuenberger $\mathrm{P}$, et al. SAPALDIA: methods and participation in the crosssectional part of the Swiss Study on Air Pollution and Lung Diseases in Adults. Soz Praventivmed 1997; 42: 67-84.

16 Ackermann-Liebrich U, Kuna-Dibbert B, Probst-Hensch NM, et al. Follow-up of the Swiss Cohort Study on Air Pollution and Lung Diseases in Adults (SAPALDIA 2) 19912003: methods and characterization of participants. Soz Praventivmed 2005; 50: 245-263.

17 Kogevinas M, Zock JP, Jarvis D, et al. Exposure to substances in the workplace and new-onset asthma: an international prospective population-based study (ECRHS-II). Lancet 2007; 370: 336-341.

18 Gonzalez JR, Armengol L, Sole X, et al. SNPassoc: an R package to perform whole genome association studies. Bioinformatics 2007; 23: 644-645.

19 R Development Core Team. R: A language and environment for statistical computing. Vienna, R Foundation for Statistical Computing, 2007. www.R-project.org 
20 Wigginton JE, Cutler DJ, Abecasis GR. A note on exact tests of Hardy-Weinberg equilibrium. Am J Hum Genet 2005; 76: 887-893.

21 Devlin B, Roeder K. Genomic control for association studies. Biometrics 1999; 55: 997-1004.

22 Price AL, Patterson NJ, Plenge RM, Weinblatt ME, Shadick NA, Reich D. Principal components analysis corrects for stratification in genome-wide association studies. Nat Genet 2006; 38: 904-909.

23 Chinn S, Downs SH, Anto JM, et al. Incidence of asthma and net change in symptoms in relation to changes in obesity. Eur Respir J 2006; 28: 763-771.

24 Vortmann M, Eisner MD. BMI and health status among adults with asthma. Obesity (Silver Spring) 2008; 16: 146-152.

25 Braback L, Hjern A, Rasmussen F. Body mass index, asthma and allergic rhinoconjunctivitis in Swedish conscripts - a national cohort study over three decades. Respir Med 2005; 99: 1010-1014.

26 Guerra S, Sherrill DL, Bobadilla A, Martinez FD, Barbee RA. The relation of body mass index to asthma, chronic bronchitis, and emphysema. Chest 2002; 122: 1256-1263.

27 Schachter LM, Salome CM, Peat JK, Woolcock AJ. Obesity is a risk for asthma and wheeze but not airway hyperresponsiveness. Thorax 2001; 56: 4-8.

28 Sookoian SC, Gonzalez C, Pirola CJ. Meta-analysis on the G-308A tumor necrosis factor- $\alpha$ gene variant and phenotypes associated with the metabolic syndrome. Obes Res 2005; 13: 2122-2131.

29 Li YP, Lecker SH, Chen Y, Waddell ID, Goldberg AL, Reid MB. TNF- $\alpha$ increases ubiquitin-conjugating activity in skeletal muscle by up-regulating $\mathrm{UbcH} 2 / \mathrm{E} 220 \mathrm{k}$. FASEB J 2003; 17: 1048-1057.

30 Tsigos C, Kyrou I, Chala E, et al. Circulating tumor necrosis factor- $\alpha$ concentrations are higher in abdominal versus peripheral obesity. Metabolism 1999; 48: 1332-1335.
31 Hotamisligil GS, Shargill NS, Spiegelman BM. Adipose expression of tumor necrosis factor- $\alpha$ : direct role in obesity-linked insulin resistance. Science 1993; 259: 87-91.

32 Gosset P, Tsicopoulos A, Wallaert B, Joseph M, Capron A, Tonnel AB. Tumor necrosis factor- $\alpha$ and interleukin- 6 production by human mononuclear phagocytes from allergic asthmatics after IgE-dependent stimulation. Am Rev Respir Dis 1992; 146: 768-774.

33 Beuther DA, Sutherland ER. Overweight, obesity, and incident asthma: a meta-analysis of prospective epidemiologic studies. Am J Respir Crit Care Med 2007; 175: 661-666.

34 Gilliland FD, Berhane K, Islam T, et al. Obesity and the risk of newly diagnosed asthma in school-age children. Am J Epidemiol 2003; 158: 406-415.

35 Kronander UN, Falkenberg M, Zetterstrom O. Prevalence and incidence of asthma related to waist circumference and BMI in a Swedish community sample. Respir Med 2004; 98: 1108-1116.

36 von Mutius E, Schwartz J, Neas LM, Dockery D, Weiss ST. Relation of body mass index to asthma and atopy in children: the National Health and Nutrition Examination Study III. Thorax 2001; 56: 835-838.

37 Jarvis D, Chinn S, Potts J, Burney P. Association of body mass index with respiratory symptoms and atopy: results from the European Community Respiratory Health Survey. Clin Exp Allergy 2002; 32: 831-837.

38 Olafsdottir IS, Gislason $\mathrm{T}$, Thjodleifsson $\mathrm{B}$, et al. $\mathrm{C}$ reactive protein levels are increased in non-allergic but not allergic asthma: a multicentre epidemiological study. Thorax 2005; 60: 451-454

39 de Koning L, Merchant AT, Pogue J, Anand SS. Waist circumference and waist-to-hip ratio as predictors of cardiovascular events: meta-regression analysis of prospective studies. Eur Heart J 2007; 28: 850-856. 